\title{
On Religious and Cultural Principles of Environmental Protection
}

\section{W sprawie religijno-kulturowych zasad ochrony przyrody}

\author{
Ryszard F. Sadowski \\ Cardinal Stefan Wyszyński University in Warsaw, Faculty of Christian Philosophy, \\ ul. Wóycickiego 1/3, building 23, 01-938 Warsaw, Poland \\ E-mail: r.sadowski@uksw.edu.pl \\ ORCID: 0000-0002-5452-2168, Scopus Author ID:55606293400
}

\begin{abstract}
The influence of religion on the human attitude to nature has been a thoroughly studied issue over the last sixty years. The present paper addresses a particular aspect of this issue, namely, it provides a comparison of religious and cultural principles characterizing animistic religions and Christianity. It also concentrates on the ecological consequences of supplanting animism with Christianity. The results of the conducted research indicate that the role of religious and cultural principles standing guard over nature is usually either overestimated or depreciated. Religion may only become an important ally making a real contribution to nature conservation at both local and global levels, providing that those principles are attributed their proper significance.
\end{abstract}

Key words: animism, Christianity, primal religions, environment, religion and ecology

\section{Streszczenie}

Wpływ religii na stosunek do przyrody jest zagadnieniem gruntownie badanym od ponad sześśdziesięciu lat. Opracowanie to podejmuje szczególny przypadek tego zagadnienia. Porównuje bowiem religijno-kulturowe zasady obecne w religiach animistycznych i chrześcijaństwie. Prezentuje ponadto ekologiczne konsekwencje wyparcia animizmu przez chrześcijaństwo. Wyniki przeprowadzonych badań wskazują, że rola zasad religijno-kulturowych stojących na straży przyrody jest zazwyczaj albo bardzo przeceniana albo niedoceniana. Tylko przyznanie tym zasadom właściwego im znaczenia może uczynić z religii ważnego sprzymierzeńca, który realnie przyczyni się do ochrony przyrody zarówno na poziomie lokalnym, jak i globalnym.

Slowa kluczowe: animizm, chrześcijaństwo, religie pierwotne, środowisko, religia i ekologia

\section{Introduction}

The mutual interaction between the world of nature and the world of culture has long been the subject of human reflection. The ancients were already aware of the fact that nature constitutes an important factor shaping the environment of human life, which is clearly illustrated in such writings as Thucydides' The History of the Peloponnesian War, Hippocrates' On Airs, Waters and Places, or Aristotle's Politics. The above works provide evidence of the ancient Greeks' conviction that the type of climate affects the temperament of a group of people inhabiting a specific area, and even the structure of their countries. In the ancient approach to the relationship between nature and culture, considerable emphasis was laid on the influence of nature on culture, since human culture was considered as weaker and more susceptible to environmental influences. For centuries, people failed to realize that their activity may affect nature and spur a process of significant changes taking place in the environment. Even at the dawn of modernity, Francis Bacon, Descartes and Galileo Galilei still naively shared the opinion about the immunity and immutability of nature (Sadowski 2015, 17-20). 
It was not before people experienced the acute effects of the ecological crisis caused by the industrial revolution, that they were able to discover the extent to which the activities of civilized humanity influenced the natural world. The experience of discovering that humanity influences the natural world forced people to examine the assumption of the immunity and immutability of nature by exposing its variability and fragility. Humanity began to realize nature's susceptibility to changes as well as the risks. The rising awareness of the general influence of culture on nature was not accompanied by any interest in the influence of religion on the environment and, consequently that issue remained neglected for a long time. Broader studies referring to the influence of religion on the environment were first initiated among Christian thinkers in the 1950s with such major works as, for example, Religious Approach to $\mathrm{Na}$ ture (1950) by W. H. Dew, Nature and Man in Biblical Thought (1953) by E. C. Rust, A Theology for Earth (1954) by Joseph Sittler, or The Work of Creation (1958) by Karl Barth. The Faith-Man-Nature Group also played an important role in the research on the relation of Christianity to the environment. The period of the most intensive research conducted by the scientists belonging to this association fell on period between the mid-1960s and the mid-1970s.

Reflection on the role of Christianity in the so-called ecological issue entered a new phase with Lynn White's publication entitled Historical Roots of Our Ecologic Crisis (1967). This seminal article became a catalyst for the ongoing discussion on the relationship between Christianity and nature having a major impact on the creation of the assumption about the anti-ecological character of Christianity. However, numerous, interdisciplinary studies on this issue point to the unusual complexity of this subject and allows to conclude that the blame attributed to Christianity for causing the environmental crisis is strongly exaggerated. The conclusion that Christinity for causing the environmental crisis is strongly exaggerated is confirmed by the research conducted within a project called the Forum on Religion and Ecology, which brings together scientists from around the world representing all the most important religious traditions. In their research on the relationship of religion to the environment, the scientists do not confine themselves strictly to the role of Christianity in the emergence of the ecological crisis, but they broaden the scope of their interest exploring a variety of religious worldviews on human attitude to nature (Tucker 2003).

Based on the research findings from the Forum on Religion and Ecology, it can be concluded that the influence of Christianity on nature is fairly ambivalent. Although the Christian tradition provides arguments justifying human interference in the natural world, it also offers arguments for the protection of the created world. The aim of this study is to present religious and cultural principles related to nature. On the one hand, it shows how Christianity eliminates the animistic principles guarding nature and, on the other, how Christianity introduces its own principles protecting nature.

\section{The role of Christianity in removing religious and cultural principles protecting nature}

Studies on the influence of Christianity on the human relationship to nature deploy various arguments to support the idea that it leads to nature's destruction. Proponents of that view point out that the anti-ecological character of Christianity is manifested in the fact that, firstly, it removes religious and cultural principles that stand guard over nature and, secondly, it introduces other principles justifying humanity's unlimited interference in nature.

One of the fundamental objections raised against Christianity in the context of eliminating the principles protecting nature is that it supplanted animistic religions, since wherever Christianity became the dominant religion, animism, which, as some scientists contend, had a much more pro-environmental character than Christianity, gradually disappeared. As animistic religions proclaimed a belief in the presence protective spirits in nature, its followers were inevitably forced to use natural resources in a limited way. They could benefit from nature's wealth providing it was necessary to support the life and functioning of their community. The fear of the guardian spirit's anger provided protection against any reckless abuse of nature. This anger could bring disaster or even death to the culprit. Any trespassing could expose the entire community to the anger of deities. Religious and cultural principles shaped in this way were respected by all community members and constituted protection against any inconsiderate abuse of nature (Sutton and Anderson 2004, 156).

The above or similar arguments are often deployed in the discussion on the role of Christianity in the ecological crisis. It seems that they were widely propagated by Lynn White in the article Historical Roots of Our Ecologic Crisis. White claims that the victory of Christianity over ancient paganism constituted the greatest psychological revolution in the history of our culture, because it radically changed the way of thinking about man and the surrounding nature. In Antiquity every tree, every spring, every stream, every hill had its own genius loci, its guardian spirit. These spirits were accessible to men, but were very unlike men; centaurs, fauns, and mermaids show their ambivalence. Before one cut a tree, mined a mountain, or dammed a brook, it was important to placate the spirit in charge of that particular situation, and to keep it placated. By destroying pagan animism, Christianity made it possible to exploit nature in a mood of indifference to the feelings of natural objects (White 1967, 1205).

White also points to the argument put forward by some scientists, namely, that the animistic worship 
of local gods of nature was replaced by the Christian cult of saints. However, this change in no respect contributed to preserving the religious principles protecting nature. For, while the animistic deities belonged to the local nature, Christian saints belonged to heaven, a reality radically different from the reality of the Earth. In addition, as White argues, the Christian religion granted man a monopoly on spirituality, which in the pagan world was enjoyed by all nature. This approach still further widened the gap between the world of culture and the world of nature, at the same time sealing the breach with pagan principles protecting nature (White 1967, 1205).

Consequently, Lynn White states that Christianity bears a huge burden of guilt for the contemporary environmental crisis. An antidote to the existing crisis that White offers is abandoning Christianity for the sake of Eastern religions that unlike Christianity put more emphasis on the relationship of man with the natural world. Another solution could also include a thorough transformation of Christianity which, as White proposes, should draw on the ideas of Saint Francis of Assisi, who emphasized the people's relationships with nature, rejected their ruling, dominant position and developed a new concept of human attitude to nature understood in terms of democracy of all God's creatures (White 1967, 1206). Other scientists also support similar opinions on the destructive influence of Christianity on nature due to its eliminating religious and cultural principles protecting nature. One of them is Arnold Toynbee, an outstanding historian and theoretician of civilization conducting research on, among others, human attitude towards the environment as the cause of the civilization collapse (Toynbee 1934). Toynbee attributes the blame for the contemporary environmental crisis to monotheistic religions, especially to Christianity, which supplanted the polytheistic religions of ancient Greece and Rome. Toynbee holds an opinion that religions of ancient Europe proclaimed a much more friendly attitude of man to nature than monotheistic religions.

Toynbee goes as far as to state that for pre-monotheistic man, nature was not just a treasure-trove of 'natural resources.' Nature was, for him, a goddess, 'Mother Earth,' and the vegetation that sprang from the Earth, the animals that roamed, like man himself, over the Earth's surface, and the minerals hiding in the Earth's bowels, all partook of nature's divinity. For primitive man, the whole of his environment was divine, and his sense of nature's divinity outlasted his technological feats of cultivating plants and domesticating animals (Toynbee 1974, 142-143).

According to Toynbee, even the emergence of philosophy did not eradicate the divine dimension of nature from the Greek culture, since in this culture, the gods were closely related to natural phenomena which were widely interpreted in a religious key (Hughes 1975, 48-49). Similarly, the anger and the bounty of ancient gods were expressed respectively in the failure of crop or in plentiful harvest (Homer 1999, book XXI, verse 130-211, book XVI, verse 215-219, Homer 1995, song XIX, verse 60-64). By contrast, the Judeo-Christian concept of the relationship between man and nature removed the previous religious and cultural constraints on human greed, which had been hampered so far by the feelings of admiration and worship that the followers of ancient polytheism cherished for nature. Man's greedy impulse to exploit nature used to be held in check by his pious worship of nature. This primitive inhibition has been removed by the rise and spread of monotheism (Toynbee 1974, 145).

In the similar vein, Ian McHarg blames the JudeoChristian tradition for supplanting animism and worship of nature which safeguarded human limited use of natural resources by propagating the attitude of respect, deference and submission (McHarg 2006, 2). McHarg's opinion is supported by Max Nicholson, who justifies the friendly relationship between the followers of primal religions and nature by a strong sense of the existing bond between their communities and the environment. Nicholson perceives this bond as a factor conditioning the formation of harmonious relationships between man and nature as well as human adaptation to the rhythm of nature's life (Nicholson 1989, 18 and 12).

Donald Worster, an American environmental historian, is another scholar blaming Christianity for eradicating religious and cultural principles that protected nature in the ancient world. However, Worster's argument is of a different character. In his opinion, the Western culture being dominated by Christianity, rejected the ancient myth of the Arcadian shepherd and replaced it with the concept of the Good Shepherd presented in John 10 (Worster 1994, 26; Sadowski 2016, 239-240). According to Worster, this change epitomizes the supplanting of the Arcadian vision of the harmonious coexistence between man and nature prevalent in Hellenic culture by the Christian vision of the destructive presence of man in the world contained in Christian culture, which he defines as imperial (Worster 1994, 29).

Worster justifies his idea in the following way: The Good Shepherd of the New Testament was more ascetic and otherworldly than his arcadian counterparts. Probably he was also meant to be more humanitarian, at least toward those fragile human creatures in his sheepfold. In the Christian version of the pastoral dream, the shepherd does not mere with nature through his flock nor is his occupation a protest against urban alienation from the natural world, both of which are key themes in the arcadian version. On the contrary, he is the defender of the flock against the hostile forces of nature - wolves, lions, bears - and his profession is to lead his lambs out of this sorry world to greener pastures (Worster 1994, 26).

What is more, Worster argues that Christianity is a catalyst for hostile references to nature, because it 
perceives it as a source of spiritual threats, carnal temptations and animal instincts that Christians should radically oppose. In his opinion Christianity has maintained a calculated indifference, if not antagonism, toward nature. The good shepherd, the heroic benefactor of man, has almost never been concerned with leading his flock to a broad reverence for life. His pastoral duties have been limited to ensuring the welfare of his human charges, often in the face of a nature that has been seen as corrupt and predatory (Worster 1994, 27).

Referring to the above-presented opinions on the question of Christianity's role in removing religious and cultural principles protecting nature, it should be stated that these allegations are largely justified, since animistic or polytheistic concepts of nature are unacceptable from the Christian point of view. A good example here is a description of the martyrdom of Saint Adalbert, the main patron of Poland, who was murdered by a pagan priest for not respecting the holy grove of pagan Prussians (Kanapariusz 2009).

However, contemporary research on the attitude to nature among the followers of animism and primal religions shows, that despite their adopting religious and spiritual principles protecting nature, they were often guilty of its excessive exploitation. A good illustration here are studies on the use of natural resources in ancient Greece, Rome, the civilizations of the Near and Far East, or in the pre-Columbian America (Hughes 1975, 68-86; Thomas 1983, 2325). Examples of nature's abuse by the followers of primal religions are also provided by studies on the myth of the noble savage and the Pristine Myth (Sadowski 2016). Both those examples refer to adherents of primal religions who had no contact with Christianity. Despite the presence of religious principles guarding nature, communities of American Indians significantly interfered in local ecosystems and the consequences of their activity are noticeable even after several hundred years (Denevan 1992, 376-377).

The question of the ecological consequences following the process of supplanting the primal religions by Christianity has recently become a subject of growing interest. A good example here is research related to the medieval processes of Christianizing the pagan tribal groups of the Eastern Baltic and their ecological consequences (Pluskowski 2019). It seems, that it is only through thorough and interdisciplinary research on this subject, that we can gain the knowledge allowing us to conduct reliable evaluation of the ecological balance of introducing or removing religious and cultural principles developed in particular religious traditions.

\footnotetext{
${ }^{1}$ All biblical texts are quoted from an online edition of the Bible available on the website: <www.catholic.org/bible/>.
}

\section{The role of Christianity in introducing reli- gious and cultural principles protecting na- ture}

Although, admittedly, Christianity eradicated religious and cultural principles protecting nature prevalent in the animistic tradition, it at the same time replaced them by other that, although for different reasons, lead to the same goal, i.e. concern for nature. Two sources may basically be indicated as regards Christian principles protecting nature, namely, the Holy Scriptures and the Church tradition. As they are interlinked and inseparable, it is sometimes difficult to clearly differentiate between those two sources. On the one hand, the Holy Scripture was written in the Church and for the Church, and on the other hand, the history of the Church is inspired by the message of the Holy Scriptures.

\subsection{Biblical inspirations of Christian care for nature} The Bible leaves no doubt that people have the right to use natural resources. However, the claim that the Bible provides people with an unlimited right to its exploitation is unjustified. Although, the JudeoChristian tradition clearly rejects the sacralization and deification of nature as well as any approaches potentially leading to pantheism, it nevertheless underlines the Creator's presence in the world and His concern for all creation.

Although, along with eliminating animistic principles that stand guard over nature, Christianity undermines its protection, it at the same time introduces new religious principles that, as it seems, to the same extent support nature's conservation. The biblical concept of nature clearly highlights human obligations to the creation as well as the reasons why people should use natural resources in a moderate and responsible manner.

It seems that one of the most important reasons for the human concern for nature issues from the awareness that God is the absolute ruler and owner of the world that He created, and that man is only His tenant, regent (Gen. 1-2; Ps. 24: 1; Chr. 29: 11-14) ${ }^{1}$. Therefore, man can use natural resources only under the powers given him by the Creator (Gen. 2: 16-17). A good illustration of the constraints on the use of natural resources is the establishment of the Sabbath year (Lev. 25: 1-12) and the division of animals into clean and unclean (Deut. 14: 4nn).

Another source of Christians' respect for nature are biblical passages evidencing God's concern for nonhuman nature. In this way, the Creator shows that nature in all its richness and diversity is valuable and important. This thesis finds its confirmation in the covenant concluded by God with Noah. The Bible emphasizes that apart from people, all living beings are also partakers of this covenant (Gen. 9: 9-11). In 
addition, the Holy Scriptures show God's concern for wild nature. In no way can this concern be justified by its utility for man (Ps. 104: 10-11, Job 38: 2527).

Christian concern for the creation also issues from biblical passages indicating that the creation is the space in which God's existence and many of His attributes are revealed - ever since the creation of the world, the invisible existence of God and his everlasting power have been clearly seen by the mind's understanding of created things (Rom. 1:20; Wisdom 13:1; Isa. 49:26).

Another biblical inspiration for Christian concern for the creation is the awareness that it itself praises the Creator (Ps. 148; Ps. 66: 1b-4). Destruction of nature would then mean depriving God of praise and belittling His glory (Rev. 5:13). In addition, the beauty of the creation provides an inspiration and encouragement for man to worship his Creator (Ecless. 43:11; Dan 3: 41-90).

One more biblical inspiration for the responsible care for nature is the Creator's command, according to which man was given the right to subdue it and be its master (Gen 1:28), but at the same time he was obliged to cultivate and take care of nature (Gen. $2: 15)$. The Creator's command is unambiguous. Man cannot usurp the role of a dictator and tyrant toward creatures, but he should rather be their caring guardian and prudent manager who remembers to govern the world in holiness and saving justice and in honesty of soul to dispense fair judgement (Wisdom $9: 3)$.

In addition, the Bible, especially in messianic prophecies, proclaims universal salvation of all creation. According to the Creator's intention, the original harmony that prevailed in the Garden of Eden will be restored at the end of time. Then, there will be perfect unity between man and God and between man and all other creatures (Isa. 11:6-9; Hos. 2:20). Christian encouragement to provide the creation with protection ends with a biblical warning that the destruction of nature will be met with a severe retribution of the Creator (Rev. 11:18).

An analysis of biblical arguments supporting prudent and responsible care for nature allows to state that the Christian tradition, to no lesser extent than animism or other primal religions, protects nature through its religious and cultural principles.

\subsection{Historical inspirations of Christian concern for nature}

Other inspirations for pro-environmental attitudes of Christians can also be found in the rich tradition of the Church. The patristic thought seems particularly abundant in this respect. A conviction that the beauty of the creation reflects the Creator's beauty, and that the creation reveals His many qualities, found its expression in the metaphor of two books. The Church Fathers were convinced that God addressed His message to man in the book of the Holy Scriptures and in the book of the creation (nature). While the first of those books is written in words, the other is inscribed in creatures (Glacken 1976, 203). It seems that this metaphor draws its inspiration from biblical passages capturing the world as a book: The heavens will be rolled up like a scroll (Isa. 34:4) and the sky disappeared like a scrolling up (Rev. 6:14).

As Socrates Scholasticus claims, there are many indications that this metaphor was first used by Anthony the Great. When asked by a philosopher how he can withstand the desert without access to books, Anthony was to answer my book, oh philosopher, is the nature of things that are made, and it is present whenever I wish to read the words of God (Socrates Scholasticus 1891, book IV, ch. 23). Gregory of Nyssa, Augustine of Hippo, John Cassian, John Chrysostom, Ephrem the Syrian and Maximus the Confessor were among those who also used the metaphor of two books in reference to nature as a space in which the Creator reveals His existence, attributes and plans. In Christian antiquity there were also writers who, although they did not directly use the expression book of nature, proclaimed the idea that God speaks to man through nature (Tanzella-Nitti 2005, 237).

A good example of such a concept of nature is provided in the words of Basil the Great: through the beauties of created things we can read God's wisdom and providence as if these beauties were letters and words (Basili Magni 1885, col. 222c-223a). Also, Saint Augustine referred to the metaphor of the book of nature in the context of discovering the Creator in the creation. Giuseppe Tanzella-Nitti quotes in this context a passage from one of his sermons Some people, in order to discover God, read a book. But there is a great book: the very appearance of created things. Look above and below, note, read. God whom you want to discover, did not make the letters with ink; he put in front of your eyes the very things that he made. Can you ask for a louder voice than that? (Tanzella-Nitti 2005, 237).

In addition, Saint Augustine points out that while the book of the Bible is available only to those who have mastered the ability of reading, the book of the universe is available to all people. It is the divine page that you must listen to; it is the book of the universe that you must observe. The pages of Scripture can only be read by those who know how to read and write, while everyone, even the illiterate, can read the book of the universe (Augustinus 1845a, col. 518).

Many early Christian writings contain inspirations for religious and cultural principles protecting nature. Saint Augustine writes about vestigia Dei signs-tropes, which the Creator inscribed in nature to be discovered by man (Augustinus 1845b, col. 302). Other Christian thinkers liken the creation to a mirror in which the Creator Himself is reflected. By observing nature, man can learn a lot about his Creator (Pedersen 1992, 22-23; Palmer et al. 2010, 82). Ori- 
gen, on the other hand, states that nature and the Holy Scriptures reflect one another to such an extent that, it seems, a person seeking answers to questions in nature and a person seeking answers to the same questions in the Scriptures will come to the same conclusions (Origenis 1862, col. 1079-1082).

The idea of defining nature as a place of God's revelation, developed in Christian antiquity as well as the metaphor of two books and mirrors prevalent in Christian literature provide yet another source of religious and cultural principles aimed at protecting nature. Consequently, the destruction of nature would be, for Christians, an offense against the Creator, as it would belittle His glory, hinder His recognition and waste the heritage entrusted to human beings.

\section{Conclusions}

It seems that many contemporary studies tend to overestimate the influence of religious and cultural principles on human decisions regarding the environment. It turns out that those principles often fail to fulfil their role, as regards both protecting nature in accordance with religious and cultural principles present in animism and primal religions as well as in Christianity. Although, it cannot be argued, that those principles have no impact on human decisions, their effectiveness is rather limited. This fact very often remains unnoticed by scholars who ascribe them a decisive role in the decision-making process. Consequently, religious traditions are burdened with responsibility for specific attitudes towards the environment. Such an approach to the problem prompted some scientist to come up with simple answers to difficult and complex issues, which in all probability contributed to the emergence of the assumption about the anti-ecological character of Christianity. This assumption is based on a simplified concept of the human decision-making process and of the significance of religious beliefs for human attitude to nature.

Another reason behind this assumption may be traced back to the very comparison made between the followers of primal religions and Christian communities as well as the ecological consequences of their functioning. James Nash draws attention to the difficulties arising from such comparisons. It must be considered that Christian communities constitute very complex and numerous social structures, whereas animist communities are mostly poorly structured and limited in number. Any comparison of communities so different in terms of numbers, complexity, pluralism, anonymity and the degree of technological sophistication is an extremely difficult process, if at all possible (Nash 1991, 90).

Conscientious evaluation of the significance of Christian principles protecting nature demands considering the fact that depriving nature of the spiritual dimension present in animistic religions and introducing the concept of transcendent God present in Christianity cannot be the only or even the essential reason for the transition from pro to anti-ecological attitudes. This view seems to be supported by Karen Gloy, who contends that irresponsible exploitation of nature rather than being a consequence of the prevalent presence of the God-Creator in the EuroAtlantic culture, is due to the lack of that presence. In Gloy's opinion, a Westerner who eliminates God from his life, takes His place becoming an alter deus with all its consequences. He aspires to be an uninhibited owner of the world, and hence, to dispose of its resources in an arbitrary manner (Gloy 1995, 164165).

There are many indications that religious beliefs are a factor having much more limited impact on human decisions than it is generally assumed. The decisionmaking process is governed by manifold conditionings and it is extremely complex. Although religious beliefs do influence human decisions, they are only one of the many factors determining man. His decisions are also influenced by other aspects such as economy, politics, aesthetics, ethics, psychology, etc. In specific cases, the complex combination of all those factors results in human decisions whose consequences may be either favourable or harmful for the environment.

Being aware of the limited role of religious and cultural principles protecting nature in securing the future of life on the Earth, one should nevertheless consider their impact on human choices. The ecological potential of religion is usually either overestimated or depreciated and poorly utilized. Religious and cultural principles should be assigned their proper role in the environmental protection in order to make religion an important ally effectively supporting initiatives undertaken to protect the Earth's ecosystem both that at the global and the local level.

The present study can be encapsulated in the following conclusions:

$\checkmark$ The charge against Christianity for supplanting animistic religious principles protecting nature is justified.

$\checkmark$ Christianity's contribution to formulating religious and cultural principles protecting the creation is underestimated.

$\checkmark$ Convictions about the effectiveness of religious and cultural principles protecting nature seem to be exaggerated. It is necessary to provide research aimed at evaluating the real impact of those principles on human decisions as regards the environment. This will allow for the optimal use of religion's ecological potential.

$\checkmark \quad$ The effectiveness of religious and cultural protection of nature as regards animistic religions and Christianity seems at least similar. 
$\checkmark \quad$ Attributing a more destructive influence on the environment to Christians than to animists and followers of primal religions is unjustified. Such comparisons often fail to consider the difference in the size of those communities or their disparate historical background due to which they are radically divergent as regards the level of civilization development and technological possibilities.

\section{References}

1. AUGUSTINUS, 1845a, Enarratio in Psalmum 45, in: Patrologia Latina, 36, ed. MIGNE J.-P., Paris, col. 518.

2. AUGUSTINUS, 1845b, Ennarratio in Psalmus 33, in: Patrologia Latina, vol. 36, ed. MIGNE J.-P., Paris, col. 302.

3. BASILI MAGNI, 1885, Homilia De Gratianum Actione, in: Patrologia Graeca, vol. 31, ed. MIGNE J.-P., Paris, col. 222c-223a.

4. DENEVAN W. M., 1992, The Pristine Myth: The Landscape of the Americas in 1492, in: Annals of the Association of American Geographers, 82(3), p. 369385.

5. GLACKEN C. J., 1976, Traces on the Rhodian Shore. Nature and Culture in Western Thought from Ancient Times to the End of the Eighteenth Century, University of California Press, Berkeley.

6. GLOY K., 1995, Das Verständnis der Natur, C.H. Beck, München.

7. HOMER, Iliad, 1999 (revised by Wyatt W.F.), Harvard University Press, Harvard.

8. HOMER, Odyssey, 1995 (revised by Dimock G.E.), Harvard University Press, Harvard.

9. HUGHES D. J., 1975, Ecology in Ancient Civilizations, University of New Mexico Press, Albuquerque.

10. KANAPARIUSZ J., 2009, Świętego Wojciecha żywot pierwszy, Słowo/obraz terytoria, Gdańsk.

11. McHARGE I., 2006, The Essential Ian McHarg: Writings on Design and Nature, Island Press, Washington D.C.

12. NASH J., 1991, Loving Nature. Ecological Integrity and Christian Responsibility, Abingdon Press, Nashville.
13. NICHOLSON M., 1989, The New Environmental Age, Cambridge University Press, Cambridge, New York.

14. ORIGENIS, 1862, Commentaris in Psalmum Primum, in: Patrologia Graeca, 12, ed. MIGNE J.P., Paris, col. 1079-1082.

15. PALMER G. E. H. et al., 2010, The Philokalia, vol. 2, Faber and Faber, London.

16. PEDERSEN O., 1992, Księga Natury, in: Zagadnienia Filozoficzne w Nauce, XIV, p. 19-50.

17. PLUSKOWSKI A., 2019, Ecologies of crusading, colonization, and religious conversion in the medieval Baltic: Terra Sacra II, Brepols, Turnhout.

18. SADOWSKI R. F., 2015, Filozoficzny spór o role chrześcijaństwa $w$ kwestii ekologicznej, TNFS (Towarzystwo Naukowe Franciszka Salezego), Warsaw.

19. SADOWSKI R. F., 2016, The Concept of «Nobilis Barbarus» in the Light of Contemporary Ecological Challenges, in: Problemy Ekorozwoju/ Problems of Sustainable Development, 11(1), p. 23-30.

20. SOCRATES SCHOLASTICUS, 1891, The Ecclesiastical History, revised with notes by A. C. ZONES, https://www.ccel.org/ccel/schaff/npnf202. ii.i.html (3.12.2019).

21. SUTTON M., ANDERSON E., 2004, Introduction to Cultural Ecology, Altamira Press, Walnut Creek.

22. TANZELLA-NITTI G., 2005, The Two Books Prior to the Scientific Revolution, in: Perspectives on Science \& Christian Faith, 57(3), p. 235-248.

23. THOMAS K., 1983, Man and the Natural World. A History of the Modern Sensibility, Pantheon Books, New York.

24. TOYNBEE A., 1934, A Study of History, Oxford University Press, London.

25. TOYNBEE A., 1974, The Religious Background of the Present Environmental Crisis, in: Ecology and Religion in History, eds. Spring D. and Spring E., Harper \& Row, New York, p. 137-149.

26. TUCKER M., 2003, Worldly Wonder: Religions Enter Their Ecological Phase, Open Court, Chicago.

27. WHITE L., 1967, The Historical Roots of Our Ecologic Crisis, in: Science, 155(3767), p. 12031207.

28. WORSTER D., 1994, Nature's Economy: A History of Ecological Ideas, Cambridge University Press, Cambridge, New York. 
